\title{
CONNECTING THEORETICAL PERSPECTIVES AND PRAXIS ON AFRICAN WOMEN LEADERSHIP AND DEVELOPMENT AGENDA
}

\author{
Costa,K. ${ }^{*}$, Ngcetane-Vika, ${ }^{* *}$ \\ Global Centre for Academic Research
}

\begin{abstract}
African women are becoming increasingly relevant in the continent's development and growth agenda. For decades, African women have been seen as a backbone and connective tissue for spiritual growth and sustainable societies, in fields such as religion, culture, economics, and politics, to name a few. This review is part of PhD studies on African women leadership development. The aim of this paper is to explore a functional connection between theoretical perspectives and practical application in real life regarding the agenda on developing leadership capabilities for women. A qualitative evidence synthesis was used as a method of inquiry and thematic expressions were developed using the COSTA QDA Technique. Results culminated in three thematic expressions that explicated a disconnect between popular theories on women development agenda and practical application in a collaborative approach. However, an emphasis was made on the requirement for women in influential leadership positions to coach and mentor others. Findings further indicated that women at grassroots level were enthusiastic and ready for programmes and environments that enable leadership capabilities, development and growth. The study concluded that formal and sustainable mentorship and coaching programmes that integrate all stakeholders (males and females) in a collaborative approach should be developed.
\end{abstract}

Key Words: African women, Leadership Capabilities, Leadership Development 


\section{INTRODUCTION}

African women are playing an increasingly important part in the continent's growth and development agenda. African women have been viewed as a pillar and a connective tissue for spiritual development and healthy economies for millennia, in leadership roles and fields such as religion, education, economics, and politics, to name a few. The creation of strong family units was seen as a citadel of hope and independence from colonial mental enslavement, as well as a movement toward a free and vibrant Africa, at the microcosm of their leadership policy. According to Ngcetane-Vika (2021), African communities place a high value on a woman's position and duty to model leadership behaviors that will allow an African child to contribute meaningfully to the construction of sustainable societies.

Worku (2017) agreed with these views, claiming that African women are critical to Africa's development in their roles as part of the formal or informal workforce, entrepreneurs, and even customers. However, it is unfortunate that African women are not given the respect they deserve for their contributions to the development of balanced, prosperous, and growing African communities. The issue of women receiving little (or no) official recognition is a global epidemic that has prompted constructive responses for action from international organizations such as the United Nations (UN), African Women Leaders Network, and African Women in Science and Engineering (Poltera, 2019).

In reaction to the United Nations' (and others') acts, some concerned with addressing concerns relating to women's leadership and community building, both in Africa and internationally, organized summits such as the 2019 Forbes Women Africa Leading Women Summit and the African and European Union's "Women in Power." The Declaration and Africa's Agenda 2063, the African Union's Women's Decade, and the UN Commission on the Status of Women all supported these goals. There are strong signs that a theoretical basis exists, both in Africa and internationally, to connect women's leadership practice and position with appropriate standards and a positive and developmental climate.

There has been a lot of discussion around analytical viewpoints that aim to incorporate multidisciplinary approaches across the realms of academia, finance, theology, politics, philanthropy, and agriculture. Disparities in leadership roles, career development, and overall women's living views in leadership related to power structures are all discussed (Stead \& Elliot, 2009; Gouws, 2008; Glass \& Cook, 2015). A critical study of mainstream leadership ideologies in relation to power relations and women's living experiences as enacted in various settings 
and circumstances is at the heart of this discussion (Lituchy, et al., 2017; Trigg \& Bernstein, 2016).

Women's leadership is a widely used construct and definition. Its pervasiveness has been shown by intuitive and reasonable use, both constructively and conceptually, in literature that is frequently taken for granted. The plausible pervasiveness of woman leadership as a concept is based on a belief closely connected and related to mainstream leadership ideologies, which have a patriarchal connotation of their own. Women's leadership is conceptually based on evolutionary theory and observational case studies that span a variety of disciplinary approaches, including political, fiscal, ethical, and socio-cultural theories. This paper aims to address the question, "How to link theory and praxis in developing African women leaders?"

\section{METHODS}

A qualitative data synthesis was undertaken to address the research query, with an emphasis on publications published between 1994 and 2020 (Grant \& Booth, 2009). A qualitative evidence synthesis (QES) is a technique for combining and comparing results from key qualitative research. The quest for and generation of themes and structures to articulate a proposition is at the heart of its technique. Purposive sampling is used to collect parts of secondary study as units of study (Duke University Medical Centre Library \& Archives, 2021). For this research, Google Scholar, Web of Science, Open Science Framework (OSF), and Crossreff were used to look for publications on the theory and practice of women's advancement in Africa. Following a critical review of the literature, the authors came to the conclusion that seven (7) publications meet the study's quality assurance requirements. Table 1 below shows metadata of these papers. This table contains abstract summaries, research methodology, and a summarised analysis to identify inconsistencies in theory and experience related to the subject matter. 


\begin{tabular}{|c|c|c|c|c|c|}
\hline$\#$ & Title & Author & Method & Summaries & Source \\
\hline 1 & $\begin{array}{l}\text { Role of African Women } \\
\text { Leaders in Inspiring } \\
\text { Women Participation in } \\
\text { Leadership: An Analysis }\end{array}$ & (Bitiyong \& Sheriff, 2019) & Qualitative & $\begin{array}{l}\text { The study discusses the role of } \\
\text { leading women leaders in } \\
\text { Africa, including how women } \\
\text { rose to positional power. The } \\
\text { researchers used } 2 \text { case } \\
\text { studies, namely Dr Nkosazana } \\
\text { Dlamini- Zuma as former and } \\
\text { first woman Chair of the AU } \\
\text { and former President of } \\
\text { Liberia, Government, HE Ellen } \\
\text { Johnson Sirleaf. These } \\
\text { studies make a proposition for } \\
\text { the pivotal role played by } \\
\text { mentoring and personal } \\
\text { development as a strategy for } \\
\text { women development }\end{array}$ & $\begin{array}{l}\text { Research } \\
\text { Gate }\end{array}$ \\
\hline 2 & $\begin{array}{l}\text { African women in } \\
\text { leadership: Current } \\
\text { knowledge and a } \\
\text { framework for future } \\
\text { studies }\end{array}$ & (Nkomo \& Ngambi, 2009) & $\begin{array}{l}\text { Qualitative } \\
\text { approach, } \\
\text { mainly } \\
\text { reviewing } \\
\text { existing } \\
\text { literature. }\end{array}$ & $\begin{array}{l}\text { This study examines the } \\
\text { phenomenon of African women } \\
\text { leadership and theoretical } \\
\text { frameworks, influence and } \\
\text { further explores feminism and } \\
\text { postcolonial theory. They also }\end{array}$ & $\begin{array}{l}\text { Online publication: } \\
\text { University of South } \\
\text { Africa }\end{array}$ \\
\hline
\end{tabular}




\begin{tabular}{|c|c|c|c|c|c|}
\hline & & & $\begin{array}{l}\text { The study } \\
\text { reviewed } \\
\text { about } 43 \\
\text { published } \\
\text { articles }\end{array}$ & $\begin{array}{l}\text { looked the male and female } \\
\text { employment population in most } \\
\text { regions of the world. }\end{array}$ & \\
\hline 3 & $\begin{array}{l}\text { Leadership: The } \\
\text { invisibility of African } \\
\text { women and the } \\
\text { masculinity of power }\end{array}$ & (Phakeng, 2015) & Qualitative & $\begin{array}{l}\text { This paper briefly examines } \\
\text { women leaders in academic } \\
\text { institutions and briefly various } \\
\text { sectors and why few are } \\
\text { occupying leadership } \\
\text { positions. And these } \\
\text { challenges are linked to } \\
\text { masculinity. }\end{array}$ & $\begin{array}{l}\text { South African Journal } \\
\text { of Science }\end{array}$ \\
\hline 4 & $\begin{array}{l}\text { Women leaders in a } \\
\text { South African higher } \\
\text { education institution: } \\
\text { Narrations of their } \\
\text { leadership operations }\end{array}$ & (Kele \& Pieterson, 2015) & $\begin{array}{l}\text { Qualitative } \\
\text { Random } \\
\text { sample of } 8 \\
\text { women } \\
\text { managers } \\
\text { interviewed }\end{array}$ & $\begin{array}{l}\text { The paper examines } \\
\text { implementation of policies that } \\
\text { should put women in positions } \\
\text { and how universities were not } \\
\text { lagging behind. The study } \\
\text { found that gender biased still } \\
\text { exist in universities. }\end{array}$ & $\begin{array}{l}\text { International Journal } \\
\text { of sustainable } \\
\text { Development } \\
\text { University of Pretoria }\end{array}$ \\
\hline
\end{tabular}




\begin{tabular}{|c|c|c|c|c|c|}
\hline 5 & $\begin{array}{l}\text { Enabling and } \\
\text { empowering women in } \\
\text { leadership in South } \\
\text { African universities - } \\
\text { Assessing needs and } \\
\text { designing a response }\end{array}$ & (Seale, et al., 2021) & Quantitative & $\begin{array}{l}\text { The paper examines Gender } \\
\text { equity and women's access to } \\
\text { senior leadership and } \\
\text { management positions in } \\
\text { universities. Further, the } \\
\text { leadership and professional } \\
\text { development competencies of } \\
\text { women in senior leadership } \\
\text { positions }\end{array}$ & Sage Journal \\
\hline 6 & $\begin{array}{l}\text { The role of women in the } \\
\text { Church in Africa }\end{array}$ & (Daniel, 2010) & Qualitative & $\begin{array}{l}\text { The paper examines the role } \\
\text { women play in African } \\
\text { churches. The paper further } \\
\text { looks at the role of women in } \\
\text { the Bible. It also examines } \\
\text { feminism and religion. }\end{array}$ & $\begin{array}{l}\text { Int. J. Social. } \\
\text { Anthropol. }\end{array}$ \\
\hline 7 & $\begin{array}{l}\text { From Cabazi to Bruma: } \\
\text { Purity Malinga's Rise to } \\
\text { Presiding Bishop of the } \\
\text { MCSA }\end{array}$ & (Kumalo, 2020) & Qualitative & $\begin{array}{l}\text { This examines the rise of } \\
\text { Purity Malinga from her } \\
\text { humble beginnings to the } \\
\text { highest office of the Methodist } \\
\text { Church of Southern Africa }\end{array}$ & $\begin{array}{l}\text { Studia Historiae } \\
\text { Ecclesiasticae }\end{array}$ \\
\hline
\end{tabular}




\section{FINDINGS}

Thematic expressions emerged from critical study and careful review of literature. Data was treated inductively using the C.O.S.T.A QDA Technique (Costa, 2020) to construct patterns, and wordclouds were used to generate visualizations (Wordclouds, 2021). Figure 1 shows how inductive coding can be used to visualize raw data from article summaries (Saldana, 2015).

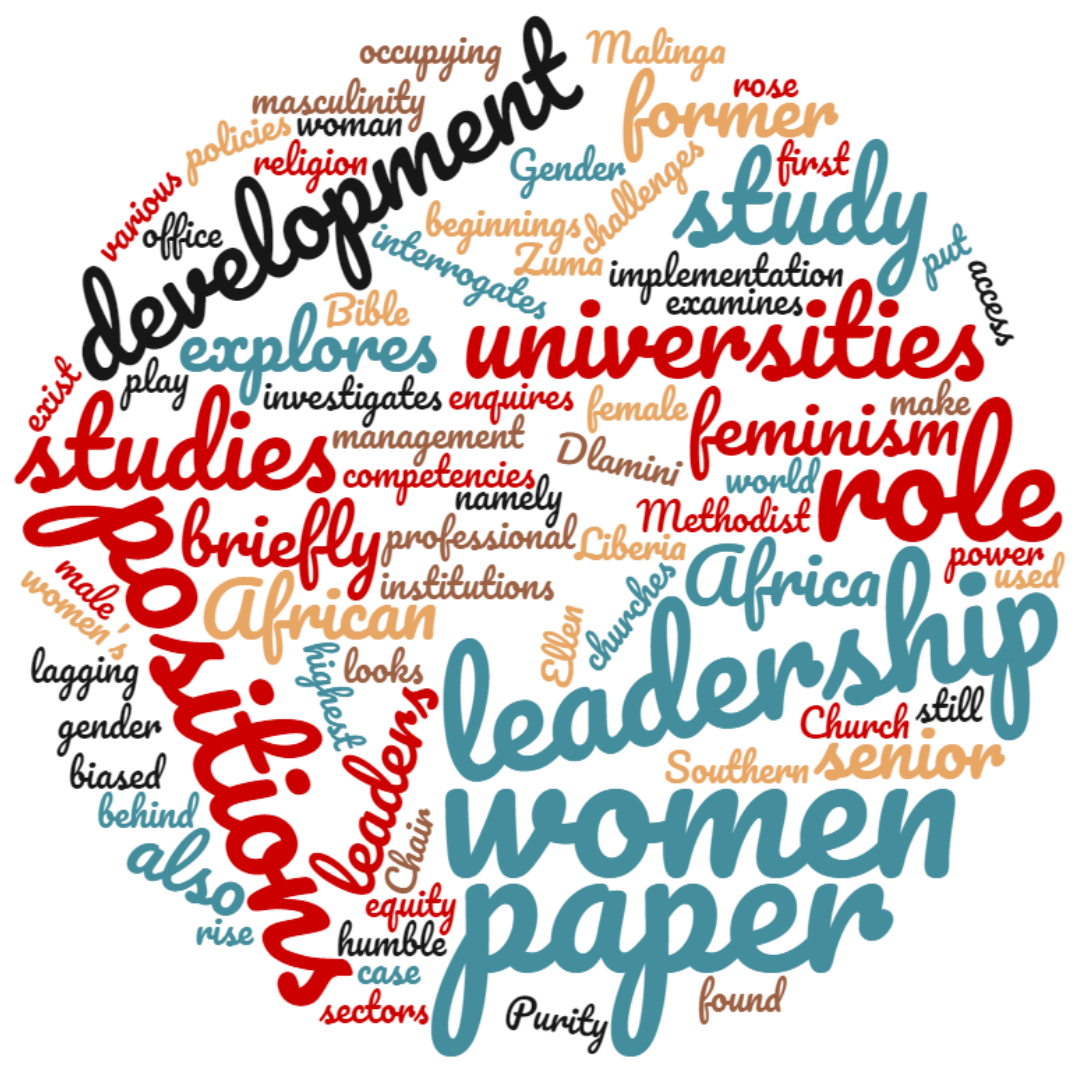

Figure 1: Women Leadership and Development

Figure 1 depicts the frequency of terms found in studies that represent women's intrinsic and extrinsic willingness and preparedness to contribute meaningfully to the African reconstruction agenda. This reconstruction would not be possible until a connection between theoretical viewpoints, epistemological foundations, and praxis is examined and understood in light of the dogmatic realities and dispositions that they actually bear. The following segment will include a thorough interpretation of thematic observations' definitions.

It's worth noting that the papers examined had the following gaps:

- Methodological - It seems that the bulk of research on the trajectory of women's dialogue in relation to leadership and growth are based on in-depth examination of the phenomenon with a constraint on generalization. 
- Theoretical - Feminist approaches are prevalent in theories that illustrate the history of women's leadership and growth.

- Practical - There is a significant imbalance in the number of female executives in all aspects of society.

Whereas there is no gap in terms of knowledge, the subject of women leadership and development is highly debated all of the world and forms part of global Millennium Development Goals, there seem to be discrepancy in the operationalisation of popular theories in this context.

\section{DISCUSSION}

This segment offers a critical analysis of the information provided in the previous section. The study's key thesis question is "How to link theory and praxis in developing African women leaders?" The following thematic expressions are introduced and analysed in order to address this question:

\section{Methods used to investigate women leadership development fail generalisation test}

This suggests that most authors and academics concentrate only on qualitative inquiry methods, ignoring the importance of triangulation (Noble \& Hill, 2019). While triangulation can also be used in qualitative analysis alone, as Lincoln and Guba (1985) proposed with their four-dimensional consistency parameters, the need for a combined approach process or quantitative studies alone would bring the debate into equilibrium. One of the distinguishing characteristics that can be considered a drawback is that the sample size of observational experiments limits the opportunity to obtain strong trust in results as they apply to the entire population of a region. The second problem with qualitative research is that it relies on subjectivity to draw conclusions. Costa (2020), Maxwell (2010), and Sandeloski (2001) concluded that the believability of qualitative analysis without 'quantifying' evidence is troublesome and difficult to apply. As a result, using a single epistomological method in this sense creates a void.

\section{Women's leadership and growth theoretical perspectives are dogmatic}

Feminist and postcolonial emancipatory schools of thinking are favoured in academic discussions about woman leadership and dialogue in Africa (Nkomo \& Ngambi, 2009; Seale, et al., 2021). While some academics have proposed that more studies be done on analytical perspectives that explain women's leadership and growth agendas, it is clear that the current 
discussions are focused on critical feminist theories. According to Phakeng, the trouble with feminist philosophies is that they are foreign to the African mindset and culture (2015). Theories such as Postcolonial theory (Nkomo \& Ngambi, 2009), ecological theory (Ettekal \& Mahoney, 2017), and economic theory (Ettekal \& Mahoney, 2017) are used to characterize the discussion in the African sense and within the feminist approach (Nkomo \& Ngambi, 2009). While there is nothing wrong with this approach, it is desirable to base inquiries on nonantagonistic perspectives as these theories are divisive. Their divisive nature of these theories manifest in debates related gender studies, which tend to correct the wrongs of the past in a punitive manner (Bitiyong \& Sheriff, 2019;Worku, 2017). These theories fail to bridge the gap between their assertions and practical application in real world.

Debates around postcolonial theory may, to some degree, divert attention away from the consequences of the role of patriarchy and masculinity in cultures and communities, as well as the reactions of members of those societies (Ashcroft, 2017). Phakeng (2015) describes these discussions as having a three-dimensional structure that portrays women as racially marginalized; as wealth and class marginalized; and as culturally disenfranchised. Epistemological inquiry that embraces these dimensions are hard to connect to ontological positions of the African women leaders and aspirants due to cultural tenets, which tends to spill onto other dimensions such as economics and status. Thus, these postcolonial theories are important but do not provide necessary nexus with praxis.

Urie Bronfenbrenner's ecological theory is a systems theory that discusses human evolution and creation and how it is affected by environmental and cultural factors. As a result, cultural traditions that are associated with patriachy as a symbol of authority, such as those proposed by Nkomo and Ngambi, are bound to interact with ecenomic theories. If evolutionary theory may help to explain the phenomenon under investigation, gender analysis may help to explain the imbalance in leadership positions in the public, private, and non-profit sectors.

These schools of thought are relevant and crucial because they embody how African women have become and are becoming. However, the dogmatic nature of these ideas is inherent in their inability to postulate a consistent direction that includes all stakeholders (females and males). The words "pragmatic" and "dogmatic" are not interchangeable. The logical pragmatic approach has a point of view that has a realistic and actionable effect, while the dogmatic approach has a connotative sense that portrays principles as undeniably true or opinionated. Theoretical approaches included in these studies offer far-fetched, unrealistic, yet unpragmatic ideas, necessitating experimentation for a nexus between philosophy and practice by those dealing with operationalising woman leadership and advancement agendas. The 
following segment seems to be doing exactly that by challenging women who are currently in positions of leadership (Kele \& Pieterson, 2015).

\section{Female leaders have a moral duty to coach and mentor others}

Seale, et al. (2021) hypothesized that women have shown an inexorable interest in personal growth and learning opportunities that will allow them to contribute to Africa's leadership and development agenda. Though studies have shown that men find it easier to cultivate, train, and tutor other men for leadership roles (Kumalo, 2020; Phakeng, 2015; Daniel, 2010), there is no evidence that mentorship is a panacea for inspiring and elevating women into leadership positions (Bitiyong \& Sheriff, 2019).

Woman leaders such as Dr. Nkosazana Dlamini-Zuma, current South African Minister of Cooperative Governance and Traditional Affairs (also former Chair of African Union) and Her Excellency Ellen Johnson Sirleaf, the former President of Liberia, are cited as pioneers and catalysts for African leadership and advancement (Bitiyong \& Sheriff, 2019). People like Dr. Ngozi Okonjo-Iweala, (the new Director General of the World Trade Organizations), Dr Phumzile Mlambo-Ngcuka (Under-Secretary-General of the United Nations for Women) are some of the dynamic women leaders who have made a mark on the African and global platform in the context of leadership and development.

Dr. Arikana Chihombori Quao, former African Union representative to the United States of America, Dr. Mamphele Ramphele, (former World Bank Managing Director and former ViceChancellor of the University of Cape Town), Purity Malinga (current presiding bishop of Methodist Church of Southern Africa and the first woman to hold that position in over 200 years of existence of Methodism in Southern Africa) are among other notable African women who have demonstrated possibilities for holding influential leadership positions in different sectors across politics, business, religion etc. There are other African women who have risen to positions of influence in fields such as politics, business, religion, culture, and academia, however, there are few studies on the role of women in mentoring and developing other women.

\section{CONCLUSION}

The study's goal was to uncover and explain a connection between theory and practice in the context of African women's leadership and advancement. The study's key goal was to identify ways to operationalize (functional) theories that are currently being debated in the academic 
circles within the social sciences about promoting women as contributors to Africa's reconstruction agenda. Three thematic expressions emerged from the study, each attempting to provide a philosophical context that functionally describes the phenomenon under examination and were articulated in the Discussion section. Although most scholarly debate on these theories were found to be dogmatic, epistemologically troublesome, and technically incoherent, a functional nexus was discovered in theories that promote mentorship and collaborative leadership styles. This discovery placed a moral duty and responsibility on women already established in leadership to coach and mentor those who are aspirant and looking for opportunities. This study is part of an ongoing research on this phenomenon under the subject of investigation, and further findings will be reported as the study progresses. Limitations thus far may be cited as inability to find quantitative studies for purposes of triangulation and as well as interviews with some of the women leaders contemplated in this study to establish their role in developing African women leaders. It is further stated that this is an ongoing study and some of these areas will be explored and reported.

\section{REFERENCES}

Ashcroft, B., 2017. Postcolonial theory. Wiley Online Library.

Bitiyong, Z. J. A. \& Sheriff, G., 2019. Role of African Women Leaders in inspiring women participation in leadership: AN analysis. African Journal of Social Sciences and Humanities Research, 2(3), pp. 12 - 27.

Costa, K., 2020. Integrating the COSTA Research framework in teaching of thematic analysis for pstgraduate students. Social Science Research Network - SSRN 3564214.

Daniel, K., 2010. The role of women in the Church in Africa. International Journal of Sociology and Anthropology, 2(6), pp. $126-139$.

Duke University Medical Centre Library \& Archives, 2021. Systematic Reviews: The process: Types of Reviews. [Online]

Available at: guides.mclibrary.duke.edu/sysreviews/types

[Accessed 8 May 2021].

Ettekal, A. V. \& Mahoney, J. L., 2017. The Ecological Systems Theory. In: K. Peppler, ed. The SAGE Encyclopedia f out of school learning. Thousand Oaks: SAGE Publications, pp. 239-241.

Glass, C. \& Cook, A., 2015. Leading at the top: Understanding women's challenges above the glass ceiling. The Leadership Quarterly, 27(1), pp. 51-63.

Gouws, A., 2008. Obstacles for women in leadership positions: The case of South Africa. Signs, 34(1), pp. 21-27.

Grant, M. J. \& Booth, A., 2009. Typology of systematic reviews. Health Information and Libraries Journal, Volume 26, pp. 91 -108. 
Kele, T. \& Pieterson, J., 2015. Women leaders in a South African higher education institution: Narrations of their leadership operations. International Journal of sustainable Development, pp. 11 - 15.

Kumalo, S., 2020. From Cabazi to Bruma: Purity Malinga's Rise to Presiding Bishop of the MCSA. Studia Historiae Ecclesiasticae, Volume 46, pp. 1-22.

Lincoln, Y. S. \& Guba, E. G., 1985. Naturalistic Inquiry. Newbury Park: Sage Publications.

Lituchy, T., Galperin, B. \& Punnett, B., 2017. LEAD: Leadership Effectiveness in Africa and the African Diaspora. New York: Palgrave Macmillan.

Maxwell, J. A., 2010. Using numbers in qualitative research. Qualitative Inquiry, 16(6), pp. 475-482.

Ngcetane-Vika, T., 2021. Servant for All Seasons: The remarkable story of Vuyani Gladstone "Vido" Nyobole. Pietermaritzburg: Bibliotos Publishers.

Nkomo, S. \& Ngambi, H., 2009. African women in leadership: Current knowledge and a framework for future studies. International Jurnal of African Renaissance Studies, 4(1), pp. 49-68.

Noble, H. \& Hill, R., 2019. Triangulation in Research. Evidence-Based Nursing, 22(3), pp. 67-68.

Phakeng, M., 2015. Leadership: The invisibility of African women and the masculinity of power. South African Journal of Science, Volume 111, pp. 1-2. http://dx.doi.org/10.17159/sajs.2015/a0126.

Poltera, J., 2019. Exploring examples of women's leadership in African contexts. Empowering women for gender equity, 33(1), pp. 3-8.

Saldana, J., 2015. The coding manual for qualitative researchers. 3rd ed. Thousand Oakes: Sage.

Sandeloski, M., 2001. The real qualitative researchers do not count: The use of numbers in qualitative research. Res Nurse Health, 24(3), pp. 23-40.

Seale, O., Fish, P. \& Schreiber, B., 2021. Women leaders in a South African higher education institution: Narrations of their leadership operations.

Stead, V. \& Elliot, C., 2009. Women's Leadership. New York: Palgrave Macmillan.

Trigg, M. \& Bernstein, A., 2016. Junctures: Case Studies in Women's Leadership: Social Movements, Rutgers: The State University.

Wordclouds, 2021. Wordclouds. [Online]

Available at: https://www.wordclouds.com/

[Accessed 8 May 2021].

Worku, A., 2017. The Critical Importance of Increasing Women Leadership in Africa. [Online] Available at: https://www.eveprogramme.com/en/29914/the-critical-importance-of-increasingwomen-leadership-in-africa/ 


\section{ABOUT AUTHORS}

*Dr King Costa is a Research Professor and Executive Dean at the Global Centre for Academic Research. He is a member of a number of research bodies and is a member of the scientific committee at the World Conference on Qualitative Research. He may be contacted at costak@researchglobal.net

** Ms Thelela Ngcetane-Vika is a social scientist and PhD researcher at the Global Centre for Academic Research. She is an author of "Servant for All Seasons" published in 2021 and is currently working on a book chapter on Dr Nelson Mandela and his jurisprudence to be published in the UK later in 2021. She is an assessor for the Women Leadership Programme at the Oxford University's Saïd Business School. She may be contacted at thelela.vika@gmail.com 